УДК 371.3::811.163.41[:78

Марина Јањић

https://doi.org/10.18485/mks_knsjkk_polozaj.2020.ch5

marina.janjic@filfak.ni.ac.rs

Универзитет у Нишу

Филозофски факултет

\title{
ЕФЕКТИ ПРИМЕНЕ МУЗИКЕ У НАСТАВИ МАТЕРЊЕГ (СРПСКОГ) ЈЕЗИКА ${ }^{1}$
}

Новији период развоја методичке мисли у области лингвометодике обележен је значајним занимањем за ефекте које изазива музика примењена у настави граматике. Ово је резултат претходних психолошких научних истраживања (Стивен Крешен, Хауард Гарднер, Клаудија Смит Салседо, Сузан Медина...) којима је доказано благотворно дејство музике у наставним процесима интерпретације граматичких наставих јединица. Песме и композиције показале су боље запамћивање нових речи, текстова и дефиниција, али су деловале изузетно позитивно и на плану језичког стваралаштва на часовима говорне културе. Рад се бави експерименталним истраживањем примене музике у обради граматичке јединице у средњој школи. Резултати истраживања потврдили су претходне хипотезе.

Кључне речи: музика, настава граматике, текст песама.

\section{1. Увод}

Још од времена старих Грка, па све до данашњих дана, музика је имала значајно место у образовању. Тако је у време Аристотела и Платона била у рангу са геометријом, астрономијом и математиком. Данас се у психологији и педагогији полази од аксиома да музички развој позитивно утиче на укупни развој когниције и интелигенције код деце, да подстиче и развија њихову креативност, језички репертоар, културу читања и социјалну интеракцију. Психолози годинама бележе позитивне резултате на пољу утицаја музике на психофизички развој детета и константују импозантне резултате. Тако су Мек Доналд и Ремзи (Мс Donald \& Ramsey) у својој студији доказали да се захваљујући му-

${ }^{1}$ Овај рад је настао у оквиру пројекта пројекту „Динамика структура српског језика" (бр. 178014), који финансира Министарство просвете, науке и технолошког развоја Републике Србије. 
зичким активностима мозак увежбава за комплексније мисаоне операције (размишљање, анализирање и доказивање), развија моћ опсервације и евалуације, способност упоређивања и контрастирања, унапређује разне физичке функције и развија фину моторику (према: Мирковић Радош 1996: 269). „Докази неуромузичких истраживања (Peretz \& Zatorre, 2005) пружили су нова сазнања која наводе да певање текстом директно успоставља кореспонденцију са зонама важним не само за музичко већ и језичко подручје (Брокина зона и Верникеова регија). У том смислу, музички материјал на коме се развија глас јавља се као битан елемент подршке психофизичког развоја и интересовања детета у појединим фазама вокалног развоја" (Стошић 2016: 61).

Да поимање уметности с временом код ученика ангажује сложеније и истанчаније когнитивне стратегије, доказују Гарднер и Хауард (Gardner\& Howard) у својој студији (Frames of Mind) још давне 1983 године. На ово се надовезују истраживања Рошерове 2003. (Raucher, Frances H.: Can Music Affect Children's Cognitive Development), који експлицирају став да и само доживљајно слушање класичне музике побољшава памћење и концентрацију. Учењем певања и свирања на неком инструменту доказано се развија спацијална (просторна) интелигенција. Такође, истраживани су утицаји музичких нумера на усвајање вокабулара страног језика (Suzanne Medina 1993), затим на механичко и учење напамет одабраних текстова (Klaudia Salcedo 2002), и сва су та испитивања указала на позитивне ефекте примене музике у настави страних језика.

У научним круговима добро је познат и Моцартов ефекат Дона Кембела који се бави позитивним утицајем музике на процес учења и развој интелигенције будући да су логичке активности попут: опажања ритма, мелодије, хармоније... важна особина музикалности. Седмо поглавље књиге посвећено је вези интелекта и музике (Унапређивање учења и креативности помоћу музике, стр. 169-201). Наиме, он сматра да помоћу ритма можемо развијати меморију и интелект јер памћење није само олакшано помоћу слика (визуелно памћење), већ и помоћу ритма: „Иако ствари које памтимо само у једном кратком периоду могу бити 
ускладиштене као слике, оне су често ускладиштене као звуци, посебно онда када памтимо речи. Краткотрајна меморија има капацитет да чува отприлике седам битова информације (дужина ове реченице, на пример). Али повезане групе информација запамћене су као један бит и тако запремина материјала која може бити ускладиштена полако расте. Информације изговорене у ритмичком обрасцу лако ће се држати заједно као јединица" (Кембел 2004: 171). Такође, у даљем тексту се наводе резултати истраживања који показују да музичке активности ученика (свирање инструмента или певање у хору) дају позитиван ефекат на пољу учења, мотивације и свеукупног понашања ученика. То стога јер музика уноси позитивно расположење и ствара подстицајну атмосферу за рад, будући да интегрише сва чула неопходна за дуготрајно памћење. Чак и као звук у позадини, она може замаскирати звуке који стварају анксиозно осећање на часу контролне или писмене вежбе и тако подстаћи креативност и концентрацију код ученика. Изучавања тима стручњака показала су да се музичким инструкцијама постиже значајан ефекат у читању и настави језика, поред тога што се развија креативност, самопоштовање ученика, међусобна сарадња и дружење, те моторне и психомоторне способности (Исто: 173).

Осим тога, музика је најпопуларнији начин да се настава учини занимљивијом па је психолози и препоручују као пример интеграције лепих уметности на часу (Георги Лозанов). На часовима српског језика, музика може служити као стимулус за говорни задатак (описивања, тумачења, дебатовања...), а избор песама и композиција може бити заснован на тематском принципу будући да се текстови песама лако могу повезати са темом наставне јединице. У том смислу, песма може послужити као основа емоционално-психолошке припреме за час у уводном делу часа, као мотивација и подстрек за дискусију или интерпретацију. Музика може послужити на часу и као мали интермецо приликом заморних и тешких вежбања или прелажења новог градива. Овај мали музички предах имао би свог дидактичког оправдања не само у виду менталне релаксације, већ и виду уметничких вербалних конструкција у текстовима песама које могу послужи- 
ти као пример њихове употребе. Риме, ритам и песничке слике могу преусмерити наставне активности на часу језика у правцу изговора, дикције, акцентуације, али и осталих делова језичког система. Наравно, њихов избор мора бити заснован на једном од наставних циљева и задатака с једне, и на ученичким преференцијама с друге стране. Учење помоћу музике може бити и спонтано и несвесно, али свакако отвара ђачке умове за нова когнитивна пространства на најлепши начин. Такође, песмом се може наставна јединица и заокружити њеним слушањем у завршном делу часа, при чему би уз пријатно осећање приликом слушања музике ученик на плану подсвести складиштио и разврставао стечено знање на часу испуњавајући своје меморијске капацитете неприметно и трајно.

\section{1. Методологија истраживања}

Будући да је утицај музике на остваривање очекиваних исхода часа у савременој наставној теорији детаљно истражен и прихваћен у области глотодидактике, тј. у наставним процесима усвајања страног језика (Ј. Редли, А. Стипанчевић) било је занимљиво испитати применљивост ових теорија у актуелној наставној пракси на часовима матерњег језика. Циљ нашег истраживања био је да испитамо какав је ефекат примене музике при обради граматике српског језика, односно, да ли су граматичка знања и умења разумљивија, јаснија и трајнија уколико се стичу уз помоћ музике. Такође, желели смо да утврдимо да ли је и колико квалитет саме средњошколске наставе граматике бољи уколико се примењује музика на часу, тј. да ли су ученици мотивисанији и сконцентрисанији при граматичким анализама ако се граматика повезује са музиком. Како бисмо добили валидне резултате, определили смо се за емпиријско истраживање наставне праксе и осмислили мали експеримент имплементирајући музичке нумере у час обраде граматичке јединице. Интерпретација добијених резултата представљена је квантитативном и квалитативном обрадом података. Истраживање је употпуњено дескриптивном и методом опсервације, а користили смо и следеће технике: тестирање, анкетирање и интервјуисање. 
Истраживање је реализовано у другом полугођу (у мају месецу) школске 2016/17. године у нишкој математичкој гимназији „Бора Станковић”. Корпусом су обухваћена укупно 94 ученика четири одељења трећег разреда ове гимназије, а која су била уједначена по успеху (иначе, реч је о престижној и врло успешној школи) и то: III-3 (25 ученика), III-4 (24 ученика), III-5 (23 ученика) и III-6 (22 ученика). Прва два одељења су (III-3 и III-4) послужила као контролна, а друга два одељења (III-5 и III-6) као експериментална. У контролним одељењима обрађена је наставна јединица Синтагме (и врсте синтагми) на класичан начин, фронталним обликом рада и дијалошком методом, док је та иста наставна јединица у експерименталним одељењима обрађена уз помоћ музиких нумера групним обликом рада. Наиме, у уводном делу часа, ученици су најпре насумице вадили наставне листиће из кутије. На полеђини сваког листића био је исписан по један стих строфе, што је била основа за груписање ученика на тај начин што су једну групу чинили они ученици на чијим листићима су исписани стихови чинили једну строфу. Након распоређивања и груписања, свака група је имала задатак да отпева своју строфу. Избор песама је урађен делимично на основу ученичких преференција, али је ипак главни критеријум био развијена реченица и присуство синтагми у тексту музичке нумере. Ради се о баладама које изводе познати интерпретатори: Здравко Чолић (еедна зима са Кристином) и Дино Мерлин (Недостајеш). На другој страни наставних листића били су исписани истраживачки задаци у вези са анализама синтагми у добијеној строфи. Дакле, текст музичких нумера послужио је као лингвометодички предложак за језичку анализу и класификацију синтагми на њене основне врсте. На основу тога, ученици су у главном делу часа обрадили ову методску јединицу коју су употпунили и додатним текстом намењеном осигурању знања да би, и на самом крају главног дела часа, срочили дефиницију и константовали врсте синтагми. У завршном делу часа надметали су се у певању обрађених строфа.

При самом крају часа, ученици су у наставне листиће унели оцену часа у виду смајлића: насмејаног, ако им се час допао, са широким осмехом ако им се час веома допао или намрштеног ако 
им се час није допао. Резултат: сви добијени смајлићи били су са (широким) осмехом. Њихова главна замерка тицала се избора песама - баладе су им биле преспоре. Но, брже нумере имају мање текста и краће исказе па су неприкладне за обраду синтагме.

Након што су прошла два-три дана од овако одржаних часова, уследило је анкетирање ученика експерименталних одељења о квалитету часа. Сачекали смо још десетак дана да бисмо неочекивано, како се не би припремали, тестирали сва четири одељења (исти тест занања примењен је и код контролних и код експерименталних одељења), и то тако што смо им дали кратку контролну вежбу са питањима и задацима о синтагмама и њиховим врстама. На овај начин проверили смо рецепцију обрађеног градива с једне, и трајност знања и могућност његове примене с друге стране.

И последњи део овог истраживања подразумева интервју са њиховом професорком српског језика, Миленом Манић. Интервју је заснован на стручној опсервацији тока и резултата спровођења експеримента у компарацији са раније стеченим искуством на традиционалним часовима граматике.

\section{3. Резултати истраживања}

\section{1. Анкетирање}

Ученици двају експерименталних одељења су попуњавали анкетни лист са десет питања о ефектима музике на часу граматике. Наиме, ученици су имали задатак да се о свакој тврдњи заокруживањем изјасне ставом: „да”, „веома” или „не”. Анкетирана су 42 ученика у експерименталним одељењима, док у контролним није било овог анкетирања будући да су наставну јединицу обрадили без музике.

Прва тврдња тицала се питања да ли им се допало да граматику уче анализом текста одабране музичке нумере. Одговор „да” заокружила су 22 ученика, „веома” 15, док је 5 ученика заокружило одговор „не”. Друга тврдња односила се на питање да ли је уводни део часа био занимљив, јер је груписање ученика за рад на тексту било организовано према строфама песме. Потврдни одговор дао је 21 ученик, опцију „веома“ је заокружило 11, док 
се 10 ученика изјаснило негативно.Треће питање се односило на лакше меморисање градива из граматике уз помоћ песме. Са тим се сложило 15 ученика, заокруживањем „веома” придружује им се још 13, док је 14 ученика заокружило одговор „не”. Четврто питање се односило на главни део часа - да ли им је начин рада био занимљив. Одговор „да” заокружио је 21 ученик, „веома” 17, док су свега 4 ученика била незадовољна. Пето питање - да ли је наставна јединица била лакша и разумљивија уз помоћ песме - подржало је 20 ученика, 15 њих се изјаснило тврдњом „веома”, док је 7 ученика имало негативан став. Шесто питање - да ли су лако дошли до дефиниције: одговор „да” заокружило је 26 ученика, „веома" 14 , док су само 2 ученика затајила. Седмо питање се тицало завршног дела часа, односно, да ли им је певање песме помогло да усвоје трајније стечено знање. Потврдан одговор заокружило је 20 ученика, „веома” 8, док је 14 ученика заокружило одговор „не”. Осмо питање било је да ли су приликом певања песме уочавали стихове. Одговор „да” дало је 26 ученика, „веома” 11, а свега 5 ученика заокружило је одговор „не”. Девето питање - да ли би волели да чешће уче граматику уз помоћ музике - дало је као резултат 20 одговора „да”, 17 „веома”, а само 5 ученика „не”. Десето питање у вези је са генерализацијом овог искуства, односно, питали смо их да ли сматрају да ће градиво из граматике уз музику лакше разумети и дуготрајно памтити. Са тим су се сложила 23 ученика, делимично се сложило њих 12, док је 7 ученика било скептично.

Дакле, од 42 ученика, најчешће се негативно изјашњавало око пет ученика, што значи да огромна већина ученика имала позитиван или изузетно позитиван став према примени музичких нумера на часу граматике. Изузетак су питања три и седам на која је негативне одговоре дало 14 ученика. Но, како је преосталих 28 ученика ипак одговорила позитивно (готово половина са изузетно јаким уверењем: „веома”), морамо константовати и овде значајну већину ученика, која и приликом меморисања градива (лакшег и трајнијег упамћивања) такође види позитивне утицаје музике. 


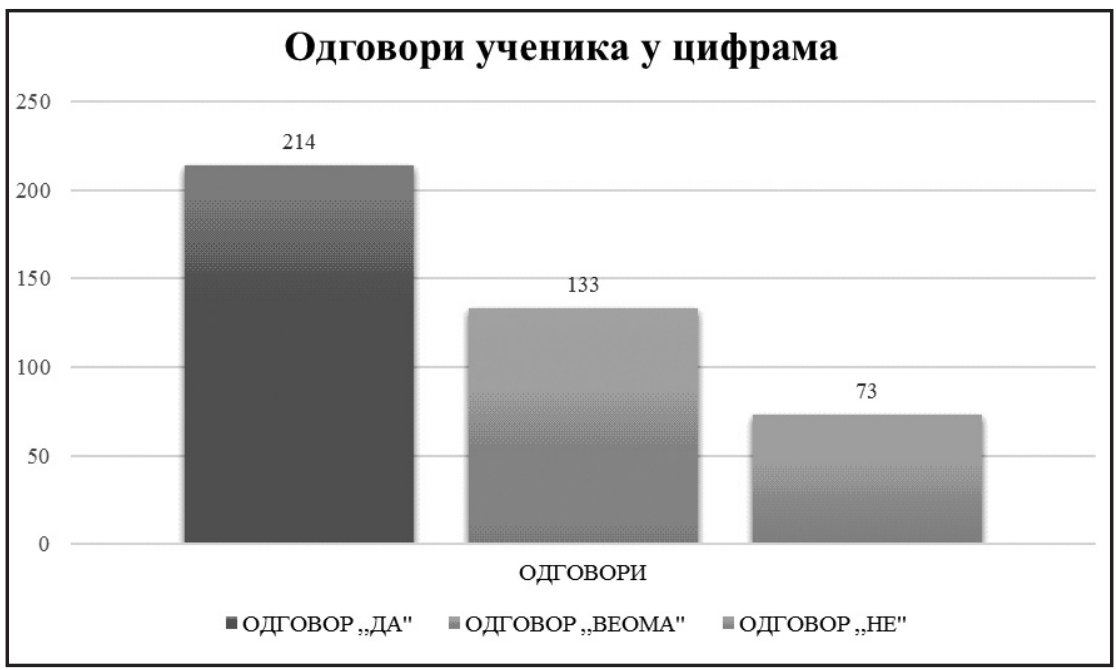

Графикон бр. 1: Одговори ученика бројчано исказани

У укупном збиру позитивних одговора, добили смо 214 позитивних одговора, 133 одговора „веома” и 73 негативних одговора, то значи: за одговор „да” изјаснило се 50,95\% ученика, за одговор „веома” 31,6\%, а за одговор „не” свега 17,3\%. Значи, 83 \% одговора имало је позитивна уверења и очекивања од примене музике на часу граматике.

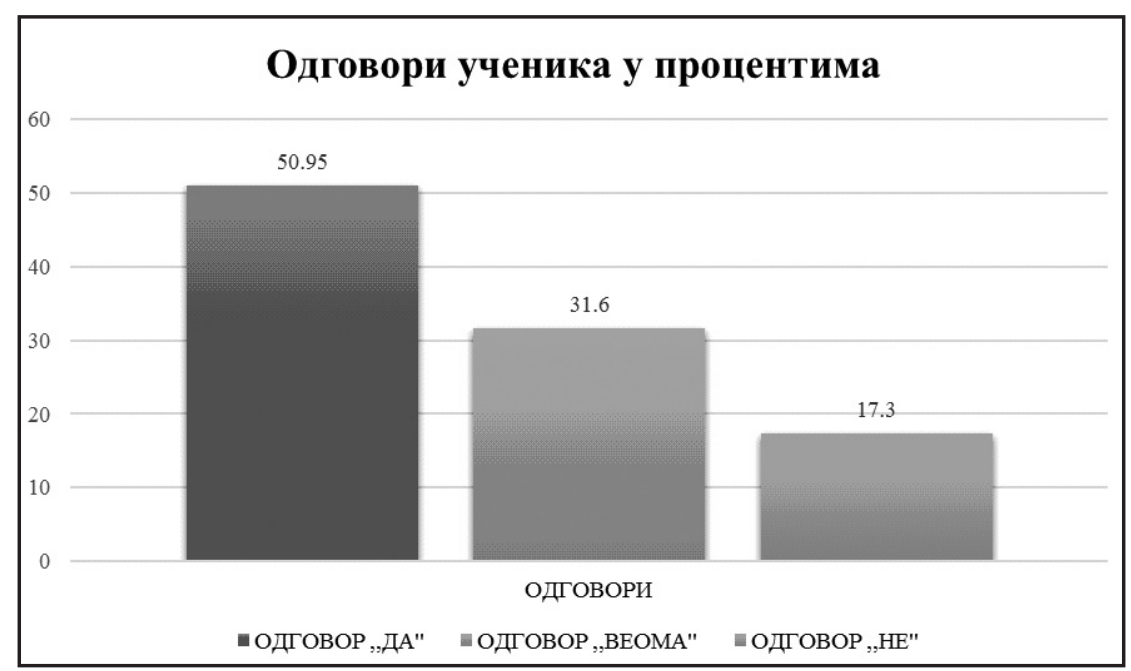

Графикон бр. 2: Одговори ученика процентуално исказани 
Марина Јањић

Као што се може и визуелно перцепирати, огромна већина ученика сматра да је учење матерњег језика на часу у свим дидактичким и психолошким ефектима успешније, занимљивије и постојаније уз помоћ музике.

\section{2. Резултати тестирања}

Тестом знања проверили смо квалитет и обим стеченог знања на часовима традиционалне и иновативне обраде са музиком. Дошли смо до занимљивих резултата. У табели је представљен број тачних одговора за свако питање у оквиру сваког одељења, док су у графиконима резултати представљени процентуално, тако да се може прегледно упоредити проценат тачних одговора на свако питање у експерименталним и контролним одељењима.

\begin{tabular}{|c|c|c|c|c|}
\hline & $3(25)^{\text {III }}$ & $4(24)$ & $5(23)^{\text {III }}$ & $6(22)^{\text {III }}$ \\
\hline 1. & 17 & 15 & 19 & 22 \\
\hline 2. & 20 & 19 & 23 & 20 \\
\hline 3. & 15 & 9 & 17 & 14 \\
\hline $\begin{array}{l} \\
\\
a^{4-}\end{array}$ & 5 & 5 & 17 & 8 \\
\hline $6^{4-}$ & 12 & 9 & 17 & 11 \\
\hline${ }^{4}{ }^{4-}$ & 8 & 9 & 14 & 10 \\
\hline${ }_{\Gamma}^{4-}$ & 8 & 9 & 16 & 12 \\
\hline$a^{5-}$ & 19 & 19 & 20 & 18 \\
\hline $6^{5-}$ & 11 & 10 & 20 & 18 \\
\hline $\mathrm{B}^{5-}$ & 19 & 19 & 21 & 20 \\
\hline$\Gamma^{5-}$ & 19 & 19 & 22 & 21 \\
\hline
\end{tabular}

Табела бр. 1: Резултати теста знања по одељењима и питањима 
На прво питање у одељењу III 3 тачне одговоре је дало 17 ученика, што представља 70 \%, у III 4 укупно 15, што чини 62,5 \%. На друго питање тачне одговоре дало је 80 \% ученика у првом, а у другом контролном одељењу 79 \%. На треће питање, тачне одговоре дало је 83,3 \% ученика у првом, а у другом контролном одељењу 37,5 \%. У експерименталним одељењима, тачне одговоре на прво питање дало је 82 \% у првом, и 100 \% у другом експерименталном одељењу. На друго питање, 100 \% у првом и 90,9 \% одељењу. На треће питање, 73 \% у првом и 63, 6\% у другом одељењу.

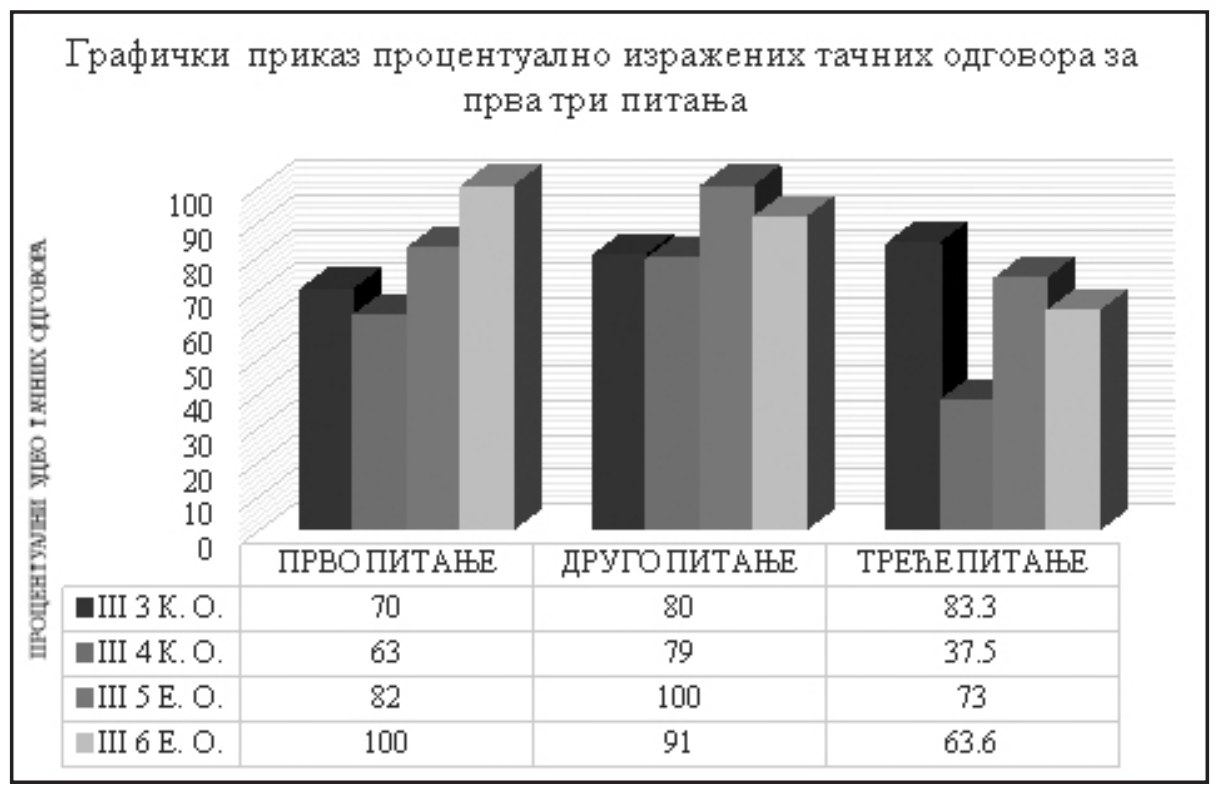

Графикон бр. 3

Четврти задатак подразумевао је анализу четири задате реченице у којима је требало заокружити синтагму, подвући унутар ње главну реч и одредити врсту. Релативно је мали број ученика који су тачно решавали целе реченице. Највећи број тачних реченица тицао се именичких синтагми. Збуњивале су их прилошке синтагме јер су их замењивали са придевским. Такође, збуњивале су их и глаголске синтагме. Чињеница да није лако одредити ни главну реч у синтагми доказана је у првој реченици, где је требало решити синтагму „на крају парка” за коју је већина ученика мислила да је прилошка сматрајући да је главна реч у овој синтаг- 
ми „на крају”, а не „парк”. Веома велики проблем је био највећем броју ученика да уочи мање синтагме у склопу већих (придевске у склопу именичких или именичке у склопу глаголских). Стога ову грешку нисмо ни узимали у разматрање.

Тако је прву реченицу четвртог задатка решило 20 \% у првом и 20, 8 \% у другом контролном одељењу. У првом експерименталним: 73,9 \% у првом и 36 \% у другом одељењу. Другу реченицу четвртог задатка решило 48 \% у првом и 37,5 \% у другом контролном одељењу. У првом експерименталним: 73,9 \% у првом и 50 \% у другом одељењу. Трећу реченицу четвртог задатка решило 32 \% у првом и 37, 5 \% у другом контролном одељењу. У првом експерименталним одељењима: 60,8 \% у првом и 45,4 \% у другом одељењу Четврту реченицу четвртог задатка решило је 32 \% у првом и 37,5 \% у другом контролном одељењу. У првом експерименталном чак 69,5 \% и 54,54 \% у другом одељењу.

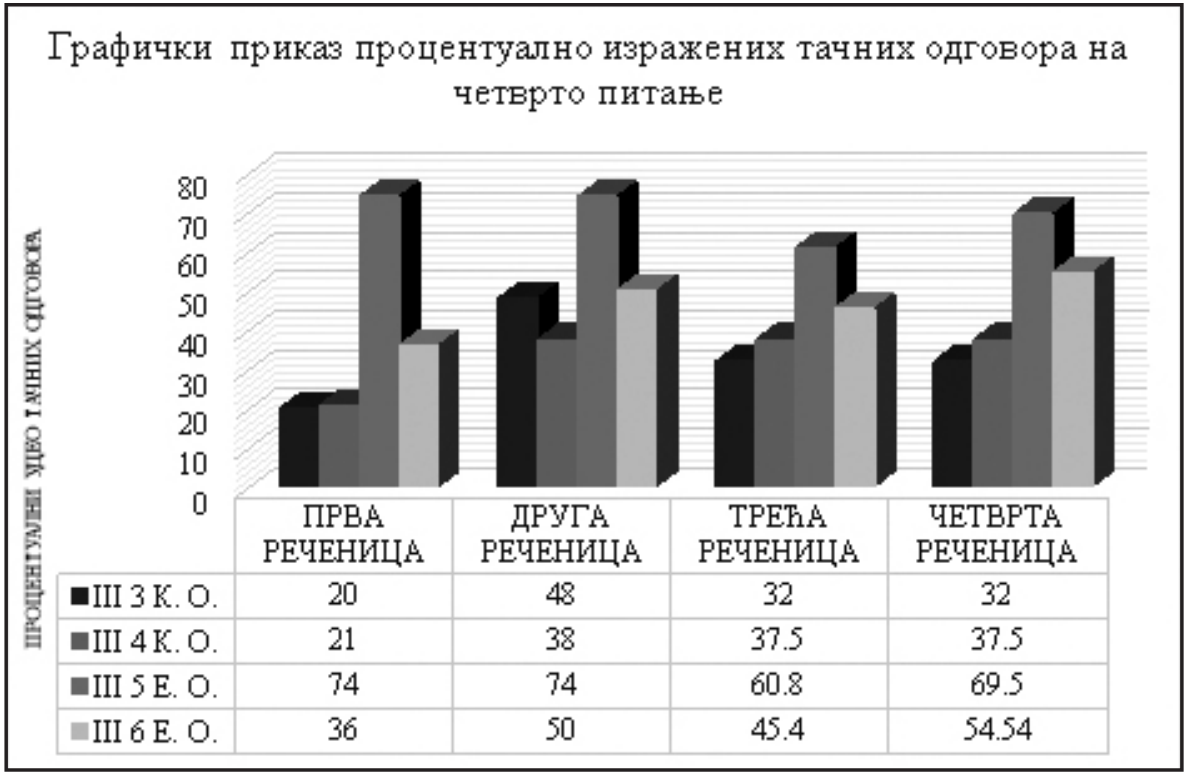

Графикон бр. 4

Пето питање било је осмишљено на начин којим бисмо повезали теорију са применом стеченог знања у говорној пракси. Овим питањем, које се грана на четири врсте синтагми (а-г), тражили смо да допуњавањем празнина ученици оформе различите 
врсте синтагми. Тежина задатка била је у томе да је на понуђену главну реч (прилог, глагол, придев, именицу) требало додати одговарајућу реч тако да се формира синтагма. Ево резултата:

У контролним одељењима, на питање под а) тачне одговоре је дало 76\% ученика у првом, односно 41,6 \% у другом одељењу. У експерименталним одељењима, резултат одговора на 5. питање под а) дало је 86,9 \%, у првом, односно 81,8 \% ученика у другом одељењу. У контролним одељењима, на питање под б) тачне одговоре је дало 44 \% ученика у првом, односно 79,1 \% у другом одељењу. У експерименталним одељењима, резултат одговора на 5. питање под б) дало је 86,9 \%, у првом, односно 81,8 \% ученика у другом одељењу. У контролним одељењима, на питање под в) тачне одговоре је дало $76 \%$ ученика у првом, односно 76 \% у другом одељењу. У експерименталним одељењима, резултат одговора на 5. питање под в) дало је 91,3 \%, у првом, односно 90,9 \% ученика у другом одељењу. У контролним одељењима, на питање под г) тачне одговоре је дало 76\% ученика у првом, односно 79,1 \% у другом одељењу. У експерименталним одељењима, резултат одговора на 5. питање под г) дало је 95,6 \%, у првом, односно 95,45 \% ученика у другом одељењу.

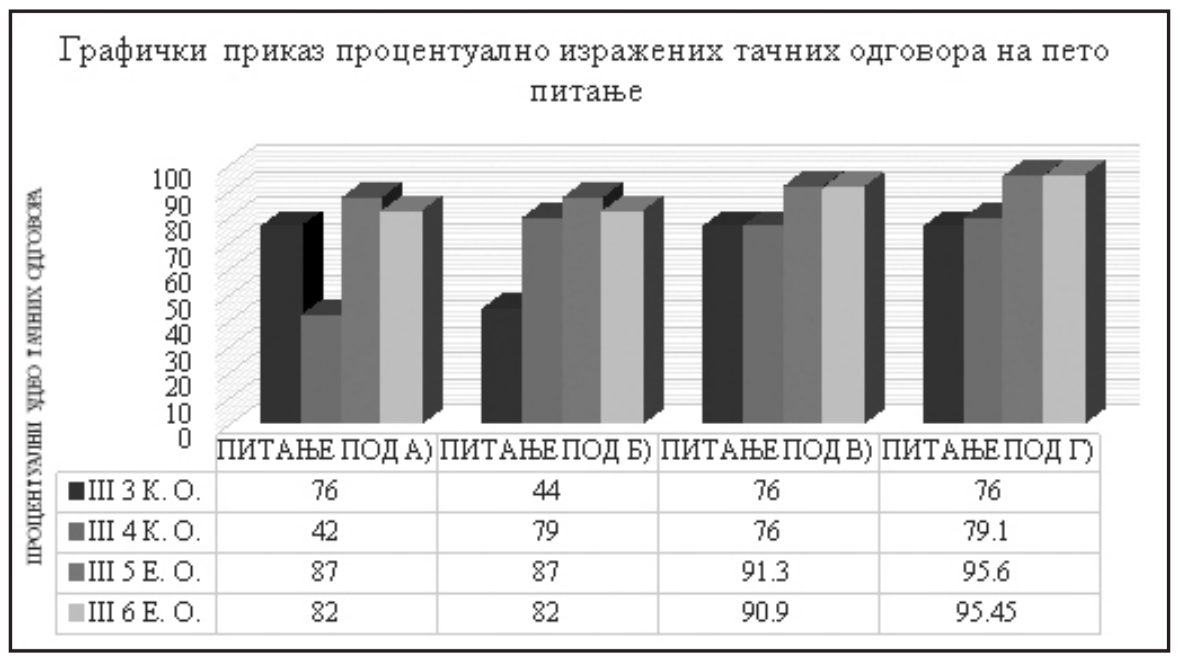

Графикон бр. 5.

На основу бројчаних и процентуалних вредности у вези са тачним одговорима ученика, стиче се недвосмислени закључак 
да су постигнућа ученика у експерименталним одељењима надмашила постигнућа ученика у контролним одељењима. Морамо нагласити да позитиван успех није изостао ни у одговорима ученика у контролним одељењима, али су резултати ипак упадљиво бољи у експерименталним одељењима. Значи, и тест знања показао је изузетно позитивне ефекте примене музике у обради новог градива на часу матерњег језика.

\section{3. Интервју са предметним професором}

Трећи део нашег истраживања подразумевао је технику опсервације од стране професорице српског језика која је учествовала у експерименту, Милене Манић. На основу стручног разговора са њом о њеним запажањима о употреби музике на часу, заокружили смо следеће извештај:

Час обраде синтагми уз помоћ музике показао се као одлично решење за мотивисање ученика. У избору песама примењена су два критеријума: да песма има довољан број синтагми, те да буде испоштован укус ученика. У уводном делу часа формирање група преко строфа прошло је одлично с обзиром на то да је реч о познатим песмама. Показало се да је то ученицима било јако занимљиво. У самом тражењу синтагми и одређивању њихових врста углавном није било проблема. Након слушања песама и формирања група, ученици су стихове посматрали као реченище и кренули су у синтаксичку анализу. У завршном делу часа ученици су певали најпре једну, а потом и другу песму. То је био један иноватнивни приступ у настави српског језика с обзиром на то да до сада нисмо спајали музику и граматику. Утисци ученика били су изузетно позитивни. Сматрају да су оваквим спојем граматике и музике научили више и да им је знање трајније. Предлагали су нове песме које се могу подвргнути синтаксичкој анализи. Такође, давали су идеје и постављали питања које се још области из граматике српског језика могу овако обрађивати. На крају могу да закључим да спајање музике и граматике има позитивно дејство на ученике. Представља добро решење за психолошку припрему и мотивацију ученика у уводном делу часа, доводи до корелације предмета српски језик и књижевност и музичке културе, те развија низ ком- 
петенција код ученика: естетичку компетенцију, сарадњу, решавање проблема, рад с подацима и информацијама, комуникацију.

Као што се може видети, за самог предметног професора ово је било ново, али позитивно наставно искуство. Јасно је експлициран став да су ученици изразили жељу да се оваква пракса устали на часовима граматике српског језика.

\section{4. Закључак}

На крају можемо закључити да су ефекти примене музике у настави граматике матерњег (српског) језика веома значајни с дидактичке стране, у смислу мотивације и подстицаја за рад ученика на часу. Са психолошког аспекта, очигледно је да је рад на тексту пратила продубљена рецепција и истраживачки ток наставних активности с једне, а са друге стране као резултат добили смо смислено учење и трајност стеченог знања са ефектима нове продукције. Потврђено је да је музика важан пратилац афективних наставних стратегија захвљујући чему се ученик на часу граматике матерњег језика осећа пријатно са пробуђеном радозналошћу и спремношћу за интеракцију са осталим ученицима и наставником. Потврду овој констатацији проналазимо у ставовима ученика и професора, али и у резултатима тестирања ученика експерименталних одељења у односу на контролне. Уверени смо да би оваква наставна пракса значајно допринела популаризацији часова граматике (матерњег језика) у нашим школама у којима се она традиционално сматра сувопарном и досадном.

\section{ЦИТИРАНА ЛИТЕРАТУРА}

Antović M. Muzika i jezik u ljudskom umu. Niš: Niški kulturni centar, 2004.

Gardner H. Frames of Mind. New York: Basic Books Inc, 1983.

Kembel D. Mocartov efekat. Beograd: Finesa, 2004.

Krashen S. Second Language Acquisition and Second Language Learning. University of Souhern California: Pergamon Press Inc,1981.

Maess B. et al. „Musical syntax is processed in Broca's area: an MEG study”. Nature Neuroscience, 4 (2001): str. 540-545.

Medina, S. L. „The Effects of Music upon Second Language Vocabulary Acquisition". Rad predstavljen na Godišnjem skupu predavača engleskog jezika govornici- 
ma drugih jezika (Kalifornija: San Francisko, mart 1990). ERICNumber: ED352834. 1993. Department of EducationInstitute of Education Statistics <https://eric. ed.gov/?id=ED352834> 4. 12. 2019.

Medina, S. L. „Using Music To Enhance Second Language Acquisition: From Theory To Practice". Lalas, J. \& Lee, S. (ur.) Language, Literacy, And Academic Development For English Language Learners. Pearson Educational Publishing, 2002.

Mirković K. R. Psihologija muzike. Beograd: Zavod za udžbenike i nastavna sredstva, 1996.

Murphy T. Music \& Song. Oxford: Oxford University Press,1998.

Peretz I. \& Zatorre R. „Brain organization for music processing”. Annu Rev. Psichology, 56, (jun 2014): str. 89-114. <http://isites.harvard.edu/fs/docs/icb.topic951137.files/musicProcessingperetzZatorre.pdf> 12.5. 2017.

Rauscher, F. H. „Can Music Instruction Affect Children's Cognitive Development?" THIS DIGEST WAS CREATED BY ERIC, THE EDUCATIONAL RESOURCES INFORMATION CENTERED 480540 2003-09-00. 2003. <http://www.eric.ed.gov/ ERICWebPortal/detail?accno=EDO-PS-03-12> 4.12. 2019.

Redli J. „Upotreba autentičnih pesama u nastavi srpskog jezika kao stranog”. Primenjena lingvistika danas - između teorije i prakse: zbornik radova sa trećeg kongresa Primenjena lingvistika danas - između teorije i prakse održanog 29.111.12.2009. u Novom Sadu. Novi Sad: Filozofski fakultet u Novom Sadu, 2012, str. 305315. <https://www.researchgate.net/publication/311808560_Upotreba_autenticnih_pesama_u_nastavi_srpskog_jezika_kao_stranog> 4.12. 2019.

Salcedo C. S. „The effects of songs in the foreign language classroom on text recall and involuntary mental rehearsal". Journal of College Teaching and Learning 7(6) (novembar 2002) <http://etd.lsu.edu/docs/available/etd-1111102 204823/ unrestricted/Salcedo_dis.pdf> 4.12. 2019.

$$
* * *
$$

Стошић А. „Функционалност уџбеничког комплета у развоју вокалних способности ученика млађих разреда основне школе". Иновације у настави, XXIX, (2016/1): стр. 60-76. Београд: Учитељски факултет. <http://scindeksclanci.ceon.rs/data/pdf/0352-2334/2016/0352-23341601060S.pdf> 15. 4. 2017.

\section{ЗНАЧЕНИЕ ПРИМЕНЕНИЯ МУЗЫКИ В ОБУЧЕНИИ ГРАММАТИКЕ СЕРБСКОГО ЯЗЫКА}

Новейший период развития методической мысли в области лингводидактики отмечен большим интересом к эффектам, которые вызывает музыка, применяемая в обучении грамматике. Это является результатом научных исследований в прошлом (Стивен Крешен, Гауард Гарднер, Смит Салседо, Сузан 
Медина...), которыми доказано благоприятное воздействие музыки в учебных процессах при интерпретации грамматического материала. Через песни и композиции лучше запоминаются новые слова, тексты и определения. Кроме того, они оказали особенно положительное влияние на фоне лингвистической практики на уроках разговорной речи.

Ключевые слова: музыка, обучение грамматике, тексты песен, содействие с музыческой културой.

\section{ПРИЛОГ БР. 1}

\section{АНКЕТА}

Заокружи свој пол: Мушки / Женски

Драги учениче,

Пред тобом је упитник којим желимо да утврдимо ставове ученика о музици у настави српског језика. Анкета је ананонимна тако да на питања можеш одговарати искрено и без страха. Анкета се спроводи у сврху унапређивања наставе српског језика. Одговорите на сваку тврдњу заокруживањем броја који јој одговара, и то на следећи начин:

\begin{tabular}{|c|c|c|c|}
\hline Тврдња & $\begin{array}{c}\text { У потпуности се } \\
\text { слажем }\end{array}$ & $\begin{array}{c}\text { Делимично се } \\
\text { слажем }\end{array}$ & Не слажем се \\
\hline $\mathbf{X}$ & 1 & 2 & 3 \\
\hline
\end{tabular}

\begin{tabular}{|c|c|c|c|c|}
\hline \multirow[b]{2}{*}{ P. 6P. } & \multirow[b]{2}{*}{ ТВРДЫА } & \multicolumn{3}{|c|}{ СТАВОВИ } \\
\hline & & $\begin{array}{c}\mathbf{y} \\
\text { ПОТПУНОСТИ } \\
\text { СЕ СЛАЖЕМ }\end{array}$ & $\begin{array}{l}\text { ДЕЛИМИЧНО } \\
\text { СЕ СЛАЖЕМ }\end{array}$ & $\begin{array}{c}\text { НЕ СЛАЖЕМ } \\
\text { СЕ }\end{array}$ \\
\hline 1. & $\begin{array}{l}\text { Музика на часовима срп- } \\
\text { ског језика учиниће грама- } \\
\text { тику занимљивијом. }\end{array}$ & 1 & 2 & 3 \\
\hline 2. & $\begin{array}{l}\text { Написала/о бих лепши пис- } \\
\text { мени састав ако би нам на- } \\
\text { ставник пустио класичну } \\
\text { композицију у току писања } \\
\text { састава. }\end{array}$ & 1 & 2 & 3 \\
\hline 3. & $\begin{array}{l}\text { Лепше бих рецитовала/о уз } \\
\text { звуке класичне музике. }\end{array}$ & 1 & 2 & 3 \\
\hline
\end{tabular}




\begin{tabular}{|c|c|c|c|c|}
\hline 4. & $\begin{array}{l}\text { Лепше бих изражајно } \\
\text { читала/о уз звуке одабране } \\
\text { музике. }\end{array}$ & 1 & 2 & 3 \\
\hline 5. & $\begin{array}{l}\text { Језичка анализа би била за- } \\
\text { нимљивија уколико бисмо } \\
\text { је радили на тексту песме } \\
\text { коју волимо да слушамо. }\end{array}$ & 1 & 2 & 3 \\
\hline 6. & $\begin{array}{l}\text { Веома би ми се допали ча- } \\
\text { сови језика уколико би на } \\
\text { почетку часа наставник } \\
\text { пустио неку песму која би } \\
\text { била у вези са градивом. }\end{array}$ & 1 & 2 & 3 \\
\hline 7. & $\begin{array}{l}\text { Музика на часу српског } \\
\text { језика ме подстиче на рад } \\
\text { јер ме опушта и чини да се } \\
\text { осећам пријатно. }\end{array}$ & 1 & 2 & 3 \\
\hline 8. & $\begin{array}{l}\text { Сматрам да певањем стихо- } \\
\text { ва омиљене песме у којима } \\
\text { се налазе језички примери } \\
\text { јединице коју обрађујемо } \\
\text { лепше и трајније увежбава- } \\
\text { мо научено градиво. }\end{array}$ & 1 & 2 & 3 \\
\hline 9. & $\begin{array}{l}\text { Музика ме подстиче на } \\
\text { маштање услед чега лакше } \\
\text { и успешније о нечему при- } \\
\text { чам, нешто описујем или } \\
\text { препричавам. }\end{array}$ & 1 & 2 & 3 \\
\hline 10. & $\begin{array}{l}\text { Контролну вежбу из срп- } \\
\text { ског језика урадила/о бих } \\
\text { успешније уз дискретну } \\
\text { музику јер не бих имала/о } \\
\text { трему. }\end{array}$ & 1 & 2 & 3 \\
\hline
\end{tabular}




\section{ПРИЛОГ БР. 2}

\section{КОНТРОЛНА ВЕЖБА}

1. Шта је то синтагма?

2. Наведи врсте синтагми?

3. Како се стварају синтагме?

4. У следећим реченицама заокружи синтагме, подвуци главне речи унутар њих и напиши којој врсти припадају:

а) На крају парка налази се тениско игралиште на које сам одлазио врло радо.

б) Моја другарица ми је, сасвим неочекивано, поставила изузетно не пријатно питање.

в) Мислећи на дечка, Уна је претерано грчевито стезала у руци свој мобилни телефон.

г) Одговарајући на постављено питање, ученик се веома полако окрену ка школској табли.

5. По угледу на први пример, формирај синтагме допуњавањем празнине:

а) вредан дивљења, пун , сличан

б) трчи брже од зеца, понаша се отмено, понео се храбро

в) мирно спавајући, претрчавши,

г) црвенкоса девојка, прозор, гледајући; улица. 